\title{
Outdoor vs indoor physical education lessons as an opportunity to shape environmental attitudes
}

\author{
Marcin Pasek \\ Gdansk University of Physical Education and Sport in Gdansk, Poland
}

\section{abstract}

Background: Systematic contact with the natural environment seems to increase the level of human sensitivity to ecological problems. The purpose of the study was to assess the impact of physical activity outdoors in nature as part of school physical education on the level of environmental attitudes

Material and methods:

220 students participated in an experimental study. The experimental group, which did exercise usually in open spaces, included 103 students. The control group, which exercised inside school, consisted of 117 students. The study period lasted two years and involved the fifth and sixth form of primary school. The authors used the part relating to attitudes in the Children's Environmental Attitude and Knowledge Scale CHEAKS in the study.

Results: The appearance of eight statistically significant differences in the field of environmental attitudes in the final study in favor of the group having outdoor physical education lessons proves the cognitively and visually stimulating role of the natural environment of physically active people. The location of physical education lessons turned out to be a much stronger condition for positive environmental attitudes than gender, place of residence, parents' education level, and subjective assessment of the financial satisfaction level.

Conclusions: These results are an incentive to further develop the young generation's contact with nature through outdoor physical education lessons.

Key words: environmental attitudes, outdoor physical education lessons.

\section{article details}

Article statistics: Word count: 4,009; Tables: 2; Figures: 0; References: 22

Received: June 2021; Accepted: October 2021; Published: November 2021

Full-text PDF: http://www.balticsportscience.com

Copyright @ Gdansk University of Physical Education and Sport, Poland

Indexation: Celdes, Clarivate Analytics Emerging Sources Citation Index (ESCI), CNKI Scholar (China National Knowledge Infrastructure), CNPIEC, DOAJ, EBSCO - Central \& Eastern European Academic Source, EBSCO - SPORTDiscus, EBSCO Discovery Service, Google Scholar, Index Copernicus, J-Gate, Naviga (Softweco, Primo Central (ExLibris), ProQuest - Family Health, ProQuest - Health \& Medical Complete, ProQuest - Illustrata: Health Sciences, ProQuest Nursing \& Allied Health Source, Summon (Serials Solutions/ProQuest, TDOne (TDNet), Ulrich's Periodicals Directory/ ulrichsweb, WorldCat (OCLC)

Funding: This research received no specific grant from any funding agency in the public, commercial, or not-for-profit sectors. Author has declared that no competing interest exists.

Corresponding author: Marcin Pasek, Gdansk University of Physical Education and Sport, 80-336 Gdansk,Gorskiego 1, Poland; e-mail: marcin.pasek@awf.gda.pl

Open Access License: This is an open access article distributed under the terms of the Creative Commons Attribution-Non-Commercial-NoDerivatives 4.0 International (https://creativecommons.org/licenses/by-nc-nd/4.0/), which permits use, distribution, and reproduction in any medium, provided the original work is properly cited, the use is non-commercial and is otherwise in compliance with the license. 


\section{INTRODUCTION}

Environmental education is a concept of training and educating the society in the spirit of respect for the natural environment. Environmental education is guided by its main idea, which can be summarized in these words: "think globally - act locally", which can be identified with highly developed ecological awareness. This awareness translates into specific attitudes [1], which are a tendency of the psychological perception of the natural environment [2]. When analyzing the shaping of attitudes in children, it can be noticed that this process usually begins with the formation of actions or emotions, and the cognitive aspect of the attitude develops at the latest [3]. For this reason, there is an obvious need for the school to support the family in the harmonious development of the child.

Physical activity in open spaces comprises a basis for many domestic health programs for the adult society, but to be implemented in adult life, physical activity patterns are realized throughout stages of school education to a large extent. New Zealand has the longest learning experience outside the classroom. In 1849 R. Huntley founded a boys' school offering outdoor activities. After one hundred years, its assumptions were restored on the initiative of L.B. Sharp, who claimed that education begins behind school doors, where one can find things described and presented in textbooks. He also suggested that the school building should be treated as a command staff that manages outdoor activities [4]. Attention is drawn to a variety of offered activities ranging from tourism and recreation, through sport including survival training, to natural and ethnographic activities, and even those relating to art and drama. The main objectives of this education involve enriching lessons with adventure and joy that comes from it, supporting individual development, supporting interpersonal relationships, developing sensitivity, and learning utilitarian behaviors [5].

Australia, following models of its neighbors and intending to safeguard the implementation of outdoor education in the future, organizes staff training. Chevalier College in New South Wales offers courses for teachers and students to prepare them for work involving outdoor education, with children aged eight or over. Courses with names like Wilderness Leadership, Wilderness Studies or Wilderness Expeditioning have both a theoretical and practical nature. The latter group includes night field trips, climbing mountain peaks, crossing rivers and streams, fast water canoeing, sailing, long-hour hiking, and finally preparing a camp for several nights on your own, among others [6].

Outdoor activities in the Oceanic zone are not rather therapeutic in view of civilization impact, being to a greater extent a natural school of life in difficult conditions. Contrary to them, English patterns of outdoor and adventure education, despite the elements of learning about and protecting nature, mainly appeal to the reduction of negative effects of the contemporary hectic life [7]. This education covers three areas: 1. Outdoor pursuits a variety of physical adventure activities designed to develop resourcefulness in hard times; 2. Outdoor studies - education forms connected with culture, architecture, civic knowledge and nature, based on observation and adaptation to changing external conditions; 3. Residential elements - learning cooperation and shaping attitudes towards overcoming difficulties together. Physical education takes about 10 percent of learning time and is enriched with outdoor education mentioned above, which is an opportunity for integrated learning of many subjects at the same time. At the end of the last century, regional outdoor educational centers were even established facilitating the organization of the so-called outdoor week [8].

Experiences of the Germans are based on combining field activities with school sports and environmental education. Known for their order and discipline, they are heading towards the construction of sports and recreational facilities offering close contact with nature located near urban areas. Recreational and adventure activities are primarily of a sports nature, while 
the experience of the natural environment is safeguarded by detailed safety and security regulations. Theoretical preparation is followed by weekly school camps, supplemented by different trips and conflict-free living with nature lessons. Students develop, among other things, the ability of quiet paddling, silent communication or discreet nature watching [9].

In 1991 in France, a decision was made to pilot the combination of outdoor activities with traditional physical education lessons. Eight specialties of outdoor lessons were approved: alpine climbing, outdoor orienteering, canoeing, cross-country cycling, downhill and crosscountry skiing, and sailing and oxygen scuba diving. To illustrate, the school board in Rouen in Normandy recommends a year-round program consisting of seven 90-minute lessons for beginners and fourteen 90-minute lessons for advanced users [10, 11].

The overall health goals guide American outdoor-environmental education. Its programs are sponsored by schools, youth organizations, churches, nature centers and private individuals with access to city parks, forests and municipal parks. The need to acquire managerial skills in this area dates back to the 1970s [12], but its practical implementation through courses for health educators has a slightly shorter history $[13,14]$. It takes place even in the far North of the USA and in Canada far away from destructive civilization influences [15]. During long winters, students go camping, ice skating, sledging, snow carving, winter orienteering, various forms of movement in deep snow, and ice-hole fishing.

Contrary to the above-mentioned positive examples, in the Polish reality, supporting the development of ecological competences is assessed by teachers as one of the less important tasks of physical education [16]. The low rank of these competences may result from the fact that combining thinking about physical education with reflection on environmental education does not enjoy long tradition in Poland, the enrichment of which depends to a large extent on engagement in educational projects connected with the natural environment. A partial response to this need were educational activities arranged by Pańczyk [17] who took up an analysis of the biological, health and educational effects of physical education in nature and in the gym. The findings proved greater effects of lessons in open spaces, which made it possible to formulate a postulate to increase the volume of the classes of this type in physical education programs.

The aim of the study was to assess the impact of physical education lessons in the outdoor and indoor formula on the level of environmental attitudes. Following the information contained in the presented sources, it was assumed that outdoor physical education lessons would result in a higher indicator of the environmental attitude of students compared to the effects of indoor physical education lessons.

\section{MATERIAL AND METHODS}

\section{PARTICIPANTS}

The study covered four schools in the Pomeranian Voivodeship in the northern part of Poland. 220 students participated in an experimental study. The experimental group, which did exercise usually in open spaces, included 49 boys and 54 girls. The control group, which exercised inside school, consisted of 63 boys and 54 girls. The study period lasted two years and involved the fifth and sixth form of primary school. Experimental group subjects were 11.26 years old $( \pm 0.32)$ during the initial test, and the control group individuals were 11.28 years $( \pm 0.32)$. During the final test, the average ages of experimental group subjects was 12.96 years $( \pm 0.32)$, and 12.98 years $( \pm 0.32)$ in the control group. The same pupils participated in the two-year project covering four terms in the fifth and fourth form. Material supervision over the classes throughout the duration of the project was exercised 
by ten teachers. In two out of eight cases, after the first year of cooperation with the class, the teacher of the group was changed for reasons unrelated to the experiment. All of them had full university education in physical education. In the schools involved in the study, they conducted classes according to the same didactic and educational plan which contained all the basic curriculum content and took into account its prospective realization both in open spaces and inside school. The initial and realized assumption was that in each school, classes were conducted by the same teacher in the experimental and control groups.

\section{MEASURE}

The study used the scheme of an educational experiment. The usefulness of this method in relation to pedagogical analyses has been repeatedly recognized so far [18].

It was assumed that experimental group subjects would take part in a significantly higher number of outdoor physical education lessons than their peers from control groups. Initially, the authors followed the earlier research assumptions of Pańczyk [17] who had set the number of outdoor lessons in the experimental groups at 75\%, and in the control groups at $25-33 \%$. In our study, the average level of $60-65 \%$ was eventually achieved in the experimental classes and $30 \%$ in the control classes.

The study of ecological attitudes applied the Children's Environmental Attitude and Knowledge Scale CHEAKS by F. Leeming et al. [19]. Ecological attitudes were measured on a Likert scale based on the earlier assumptions of Ogunjinmi et al. [20], from very false $=1$, mostly false $=2$, not sure $=3$, mostly true $=4$, to very true $=5$.

In two points, necessary corrections were made to the text in relation to the American original [19] and its Nigerian version [20]. They consisted in replacing the country of the USA / Nigeria with Poland and the American / Nigerian currency with the Polish one in the questionnaire.

The environmental attitudes scale consisted of thirty-six statements which were divided into six categories: animals, pollution, general issues, water, energy, and recycling. Each of the categories consisted of six statements.

Before the research, the following assumptions were made:

1. Increased contact with nature lasting two years during physical education lessons is sufficient to improve the indicators of environmental attitudes.

2. In addition to forms of physical activity outside the classroom with more positive environmental attitudes, it seems that the higher education of the parents of the studied pupils and perhaps the place of residence also seem to be decisive. According to previous observations [21], the industrial environment which does not take into account the harmonious whole of human needs induces the deprivation of the need to experience beauty and order. Under these circumstances, identification with an ecologically transformed environment may lead to low self-esteem and malaise.

\section{DATA ANALYSIS}

In statistical analysis, parametric descriptive statistics (Mean, SD) were applied to characterize variables. Student's T-test was used to study the differences between the means of the compared groups and Pearson's $\mathrm{r}$ to study the relationships between variables (linear correlation coefficient). Linear regression analysis of the explained variables was also conducted. The results which met the condition of $\mathrm{p}<0.05$ were considered statistically significant. 


\section{RESULTS}

In terms of environmental attitudes, eight cases of significant advantage of students from the experimental group were found in relation to the total number of thirty-six statements. As with the knowledge test, all these differences occurred in the final study. They were associated with a concern for animals (theorems 4 and 6), a concern for pollution (theorems 1, 5 and 6) as well as a concern for general issues (theorems 3, 5 and 6). The results of the initial and final research on environmental attitudes are presented in Tables 1-2.

Table 1. Comparison of the results of the environmental attitude study in the experimental and control group in the initial measurement

\begin{tabular}{|c|c|c|c|c|}
\hline \multirow[t]{2}{*}{ Attitudinal statement } & Treatment group & Control group & \multirow{2}{*}{$\mathrm{t}$} & \multirow{2}{*}{$\mathrm{p}$} \\
\hline & Mean \pm SD & Mean \pm SD & & \\
\hline \multicolumn{5}{|l|}{ Item 1: Concern for animals } \\
\hline $\begin{array}{l}\text { I I will be willing to stop buying some } \\
\text { products to save animals' lives }\end{array}$ & $2.82 \pm 1.22$ & $2.95 \pm 1.18$ & 0.81 & 0.417 \\
\hline $\begin{array}{l}2 \text { I will give } 20 \text { zloty out of my pocket } \\
\text { money per month to help protect } \\
\text { wild animals }\end{array}$ & $2.87 \pm 0.77$ & $2.96 \pm 0.95$ & 0.77 & 0.437 \\
\hline $\begin{array}{l}3 \text { I get angry when I think about } \\
\text { companies testing products on } \\
\text { animals }\end{array}$ & $2.93 \pm 0.70$ & $2.90 \pm 0.77$ & -0.25 & 0.795 \\
\hline $\begin{array}{l}4 \text { I will put up a bird house near my } \\
\text { house }\end{array}$ & $2.86 \pm 1.00$ & $3.05 \pm 0.87$ & 1.47 & 0.141 \\
\hline $\begin{array}{l}5 \text { I will ask my parents to stop buying } \\
\text { products from animal furs }\end{array}$ & $2.81 \pm 0.93$ & $2.91 \pm 0.98$ & 0.75 & 0.448 \\
\hline $\begin{array}{l}6 \text { It makes me sad to see houses } \\
\text { being built where animals used to live }\end{array}$ & $2.81 \pm 0.81$ & $2.80 \pm 0.79$ & -0.11 & 0.911 \\
\hline \multicolumn{5}{|l|}{ Item 2: Concern for Energy } \\
\hline $\begin{array}{l}1 \text { To save energy. I will turn off lights } \\
\text { at home when they are not in use }\end{array}$ & $2.96 \pm 0.65$ & $2.84 \pm 0.84$ & -1.11 & 0.266 \\
\hline $\begin{array}{l}2 \text { It frightens me to think about how } \\
\text { much energy is being wasted }\end{array}$ & $2.95 \pm 0.79$ & $3.00 \pm 1.02$ & 0.38 & 0.698 \\
\hline $\begin{array}{l}3 \text { I leave the refrigerator open while } \\
\text { I decide on what to get out }\end{array}$ & $3.03 \pm 0.93$ & $2.89 \pm 0.82$ & -1.18 & 0.235 \\
\hline $\begin{array}{l}4 \text { I will be willing to save energy } \\
\text { using less air conditioning }\end{array}$ & $2.90 \pm 0.84$ & $2.75 \pm 0.87$ & -1.29 & 0.198 \\
\hline $\begin{array}{l}5 \text { It makes me feel happy to see } \\
\text { people trying to save energy }\end{array}$ & $2.96 \pm 0.81$ & $2.86 \pm 1.08$ & -0.74 & 0.454 \\
\hline $\begin{array}{l}6 \text { To save energy. I will be willing } \\
\text { to use dimmer light bulbs }\end{array}$ & $2.94 \pm 0.77$ & $2.93 \pm 0.84$ & -0.09 & 0.926 \\
\hline \multicolumn{5}{|l|}{ Item 3: Concern for water } \\
\hline $\begin{array}{l}1 \text { I do not let the water facet run } \\
\text { when it is not necessary }\end{array}$ & $2.85 \pm 0.93$ & $2.86 \pm 0.86$ & 0.07 & 0.941 \\
\hline $\begin{array}{l}2 \text { To save water. I will be willing to } \\
\text { use less water when I bath }\end{array}$ & $2.86 \pm 0.89$ & $3.00 \pm 0.90$ & 1.18 & 0.236 \\
\hline $\begin{array}{l}3 \text { I will be willing to turn off water tap } \\
\text { while I wash my hands in order to } \\
\text { save water }\end{array}$ & $3.04 \pm 0.86$ & $2.94 \pm 0.89$ & -0.83 & 0.404 \\
\hline $\begin{array}{l}4 \text { I turn off the water in the sink while } \\
\text { I brush my teeth }\end{array}$ & $2.84 \pm 0.66$ & $2.93 \pm 0.79$ & 0.87 & 0.384 \\
\hline $\begin{array}{l}5 \text { It upsets me when I see people use } \\
\text { too much water }\end{array}$ & $2.93 \pm 1.17$ & $2.98 \pm 1.04$ & 0.34 & 0.733 \\
\hline $\begin{array}{l}6 \text { I am worried about running out of } \\
\text { water }\end{array}$ & $2.84 \pm 1.08$ & $2.70 \pm 0.84$ & -1.10 & 0.270 \\
\hline \multicolumn{5}{|l|}{ Item 4: Concern for pollution } \\
\hline $\begin{array}{l}1 \text { I would be willing to ride the bus } \\
\text { to more places in order to reduce air } \\
\text { pollution }\end{array}$ & $3.06 \pm 0.93$ & $3.05 \pm 1.05$ & -0.12 & 0.901 \\
\hline $\begin{array}{l}2 \text { I would be willing to write letters } \\
\text { asking people to help reduce pollution }\end{array}$ & $3.04 \pm 0.94$ & $3.12 \pm 1.02$ & 0.59 & 0.550 \\
\hline
\end{tabular}




\begin{tabular}{|c|c|c|c|c|}
\hline \multirow[t]{2}{*}{ Attitudinal statement } & Treatment group & Control group & \multirow{2}{*}{$\mathrm{t}$} & \multirow{2}{*}{$\mathrm{p}$} \\
\hline & Mean \pm SD & Mean \pm SD & & \\
\hline $\begin{array}{l}3 \text { I have not written someone about } \\
\text { a pollution problem }\end{array}$ & $2.77 \pm 1.03$ & $2.93 \pm 0.84$ & 1.21 & 0.224 \\
\hline $\begin{array}{l}4 \text { I have asked others what I can do } \\
\text { to help reduce pollution }\end{array}$ & $2.67 \pm 0.94$ & $2.63 \pm 1.00$ & -0.35 & 0.721 \\
\hline $\begin{array}{l}5 \text { I get angry about the damages } \\
\text { pollution does to the environment }\end{array}$ & $3.04 \pm 0.66$ & $3.07 \pm 0.70$ & 0.30 & 0.760 \\
\hline $\begin{array}{l}6 \text { I am not frightened about the } \\
\text { effect of pollution on my family }\end{array}$ & $2.89 \pm 0.80$ & $2.77 \pm 1.05$ & -0.90 & 0.366 \\
\hline \multicolumn{5}{|l|}{ Item 5: Concern for general issues } \\
\hline $\begin{array}{l}1 \text { I would be willing to give } 20 \text { zloty } \\
\text { out of my own pocket money to help } \\
\text { the environment }\end{array}$ & $2.86 \pm 0.84$ & $2.90 \pm 0.80$ & 0.37 & 0.707 \\
\hline $\begin{array}{l}2 \text { I would go from house to house to } \\
\text { pass out environmental information }\end{array}$ & $2.83 \pm 0.89$ & $2.90 \pm 0.85$ & 0.60 & 0.547 \\
\hline $\begin{array}{l}3 \text { I have talked to my parent about } \\
\text { the environment }\end{array}$ & $2.90 \pm 1.18$ & $2.97 \pm 0.77$ & 0.53 & 0.592 \\
\hline $\begin{array}{l}4 \text { I often read stories that are mostly } \\
\text { about the environment }\end{array}$ & $3.01 \pm 0.85$ & $3.03 \pm 0.97$ & 0.11 & 0.905 \\
\hline $\begin{array}{l}5 \text { I am frightened to think that people } \\
\text { do not care about the environment }\end{array}$ & $2.99 \pm 0.67$ & $2.90 \pm 0.75$ & -0.86 & 0.386 \\
\hline $\begin{array}{l}6 \text { I do not worry about environmental } \\
\text { problems }\end{array}$ & $2.89 \pm 0.80$ & $2.77 \pm 1.05$ & -0.90 & 0.366 \\
\hline \multicolumn{5}{|l|}{ Item 6: Concern for recycling } \\
\hline $\begin{array}{l}1 \text { I would not be willing to separate } \\
\text { my family's trash for recycling }\end{array}$ & $2.86 \pm 0.84$ & $2.91 \pm 0.80$ & 0.45 & 0.650 \\
\hline $\begin{array}{l}2 \text { I would be willing to go from house } \\
\text { to house asking people to recycle }\end{array}$ & $2.83 \pm 0.89$ & $2.89 \pm 0.85$ & 0.52 & 0.597 \\
\hline $\begin{array}{l}3 \text { I have asked my family to recycle } \\
\text { some of the things that are at home } \\
\text { for recycling }\end{array}$ & $2.90 \pm 1.18$ & $2.96 \pm 0.76$ & 0.47 & 0.636 \\
\hline $\begin{array}{l}4 \text { I do not separate things at home } \\
\text { for recycling }\end{array}$ & $3.01 \pm 0.85$ & $3.04 \pm 0.97$ & 0.18 & 0.851 \\
\hline $\begin{array}{l}5 \text { It makes me happy when people } \\
\text { recycle used bottles. cans and paper }\end{array}$ & $2.99 \pm 0.67$ & $2.91 \pm 0.74$ & -0.78 & 0.435 \\
\hline $\begin{array}{l}6 \text { I get upset when I think of the } \\
\text { things people throw away that could } \\
\text { be recycled }\end{array}$ & $3.06 \pm 0.95$ & $3.04 \pm 1.06$ & -0.18 & 0.853 \\
\hline
\end{tabular}

Table 2. Comparison of the results of the environmental attitude study in the experimental and control group in the initial measurement

\begin{tabular}{|c|c|c|c|c|}
\hline Attitudinal statement & Mean $\pm S D$ & Mean $\pm S D$ & $t$ & $\mathrm{p}$ \\
\hline $\begin{array}{l}1 \text { I will be willing to stop buying some } \\
\text { products to save animals' lives }\end{array}$ & $2.88 \pm 0.79$ & $2.88 \pm 0.92$ & -0.02 & 0.978 \\
\hline $\begin{array}{l}3 \text { I get angry when I think about } \\
\text { companies testing products on } \\
\text { animals }\end{array}$ & $2.94 \pm 0.78$ & $3.04 \pm 0.88$ & 0.88 & 0.375 \\
\hline $\begin{array}{l}4 \text { I will put up a bird house near my } \\
\text { house }\end{array}$ & $3.35 \pm 0.83$ & $2.89 \pm 0.67$ & -4.52 & 0.001 \\
\hline $\begin{array}{l}6 \text { It makes me sad to see houses } \\
\text { being built where animals used to live }\end{array}$ & $3.24 \pm 0.95$ & $2.83 \pm 1.04$ & -2.99 & 0.003 \\
\hline
\end{tabular}


Attitudinal statement

\begin{tabular}{cc} 
Treatment group & Control group \\
\hline Mean \pm SD & Mean \pm SD
\end{tabular}

p

Item 2: Concern for Energy

1 To save energy. I will turn off lights at home when they are not in use

$\begin{array}{llll}2.90 \pm 0.83 & 3.05 \pm 0.89 & 1.26 & 0.207 \\ 2.89 \pm 0.85 & 3.05 \pm 0.98 & 1.26 & 0.206 \\ 2.95 \pm 0.78 & 2.81 \pm 1.02 & -1.12 & 0.263 \\ 3.01 \pm 0.98 & 2.83 \pm 0.93 & -1.39 & 0.163 \\ 2.92 \pm 0.77 & 3.01 \pm 0.66 & 0.97 & 0.331 \\ 3.05 \pm 1.10 & 2.89 \pm 0.85 & -1.21 & 0.227\end{array}$
to use dimmer light bulbs

Item 3: Concern for water

1 I do not let the water facet run when it is not necessary

$\begin{array}{llll}2.99 \pm 1.14 & 2.85 \pm 0.89 & -0.98 & 0.324 \\ 2.94 \pm 0.92 & 2.85 \pm 0.93 & -0.69 & 0.488 \\ 2.91 \pm 0.78 & 2.92 \pm 1.12 & 0.07 & 0.937 \\ 3.02 \pm 0.86 & 3.02 \pm 0.84 & -0.03 & 0.975 \\ 2.92 \pm 0.95 & 2.99 \pm 0.66 & 0.62 & 0.530 \\ 2.79 \pm 0.80 & 2.87 \pm 0.85 & 0.67 & 0.502\end{array}$

2 To save water. I will be willing to use less water when I bath

3 I will be willing to turn off water tap while I wash my hands in order to save water

4 I turn off the water in the sink while I brush my teeth

5 It upsets me when I see people use too much water

$2.79 \pm 0.80$

$+0.85$

$3.16 \pm 0.85$

$2.88 \pm 0.82$

$-2.51$

0.012

to more places in order to reduce air pollution

2 I would be willing to write letters asking people to help reduce pollution

$2.84 \pm 0.87$

$-1.36$

0.174

3 I have not written someone about a pollution problem

$2.89 \pm 0.80$

$2.94 \pm 1.13$

0.35

0.726

4 I have asked others what I can do to help reduce pollution

$2.70 \pm 0.89$

$2.86 \pm 0.85$

1.31

5 I get angry about the damages pollution does to the environment

$3.39 \pm 0.90$

$3.00 \pm 0.66$

$-3.68$

0.001

6 I am not frightened about the effect of pollution on my family

$3.14 \pm 0.89$

$2.90 \pm 0.87$

$-2.01$

0.045

Item 5: Concern for general issues

1 I would be willing to give 20 zloty out of my own pocket money to help the environment

$2.88 \pm 0.86$

$2.80 \pm 1.21$

$2.88 \pm 0.78$

$2.92 \pm 0.70$

$2.86 \pm 0.99$

$2.81 \pm 1.01$

$-2.56$

$2.82 \pm 0.81$

$3.10 \pm 0.83$ problems

about the environment

$5 \mathrm{I}$ am frightened to think that people do not care about the environment

Item 6: Concern for recycling

1 I would not be willing to separate my family's trash for recycling

2 I would be willing to go from house to house asking people to recycle

$\begin{array}{lll}3.07 \pm 1.10 & 2.94 \pm 0.62 & -1.07 \\ 3.12 \pm 0.97 & 2.94 \pm 0.87 & -1.41\end{array}$

0.198

0.022

0.578

0.001

0.011 


\begin{tabular}{lcccc} 
Attitudinal statement & Treatment group & Control group & & $\mathrm{p}$ \\
\cline { 2 - 3 } & Mean \pm SD & Mean \pm SD & & 0.850 \\
\hline $\begin{array}{l}3 \text { I have asked my family to recycle } \\
\begin{array}{l}\text { some of the things that are at home } \\
\text { for recycling }\end{array}\end{array}$ & $2.95 \pm 0.83$ & $2.97 \pm 0.95$ & 0.18 & 0.510 \\
$\begin{array}{l}4 \text { I do not separate things at home } \\
\text { for recycling }\end{array}$ & $2.97 \pm 0.99$ & $2.88 \pm 0.84$ & -0.65 & 0.147 \\
$\begin{array}{l}5 \text { It makes me happy when people } \\
\text { recycle used bottles. cans and paper }\end{array}$ & $3.11 \pm 0.69$ & $2.96 \pm 0.82$ & -1.45 & 0.119 \\
\begin{tabular}{l}
$\begin{array}{l}\text { I get upset when I think of the } \\
\text { things people throw away that could } \\
\text { be recycled }\end{array}$ \\
\hline
\end{tabular}
\end{tabular}

Figures marked in bold indicate a statistically significant difference

\section{DISCUSSION}

In light of the research results demonstrated in this paper, outdoor physical education lessons appear to be a crucial factor shaping environmental attitudes. The assessment of environmental attitudes in consideration of the location of physical education lessons, broken down by outdoor and indoor activities, has not been taken into account in the previous studies. Other studies dealt with the environmental attitudes of students without analyzing the determinants of these attitudes [22], showing that $80 \%$ of students preparing for studies in Alexandria had a negative attitude to environmental issues, whereas the remaining $20 \%$ represented indifference. The studies conducted by Ogunjinmi et al. [20] showed that the status of school, namely its public or private character $(\beta=-10.08 ; \mathrm{p}<0.05)$ comprised the only determinant of students' environmental attitudes. Other individual factors, such as age, gender, education level and the nature of the class, broken down by its scientific and artistic profile, were not related to the students' environmental attitudes.

The emergence of differences in environmental attitudes in the final study for the benefit of the group having physical education lessons outside classroom may indicate the cognitive and visual stimulating role of natural environment in engaging in outdoor forms of physical activity. In the study group, physical activity in the natural environment turned out to be a much stronger determinant of positive ecological attitudes than other analyzed factors, such as gender, place of residence, parents' education level, and subjective assessment of financial satisfaction.

The new concept of general education, assuming a departure from the propaedeutic and encyclopedic model in favor of a more utilitarian one, prefers to provide students with such information and skills that will allow them, inter alia, to coexist with the surrounding natural environment. In this approach, physical education should be understood as a carrier of the imperative of work on oneself and mainly include activities which create an alternative attitude towards one's own health and physical fitness, especially in regular contact with nature. This environment is conducive to self-education based on students' own activity, strengthened by the emotional foundation that is provided by the specific charm of classes conducted outside school.

\section{CONCLUSION}

Outdoor activities effectively prepare students for the proper organization of free time, shaping permanent health and leisure habits. This will allow for more effective shaping of environmental awareness of young people, for whom contact with nature would not be limited only to physical improvement, but it would also become a source of spiritual values, in which the integration of physical and ecological culture towards future culture of life can be seen. 


\section{REFERENCES}

[1] Maloney MP, Ward MP, Braucht GM. A revised scale for the measurement of ecological attitudes and knowledge. Am Psychologist 1975;30:787-790. https://doi.org/10.1037/h0084394

[2] Milfont TL. Psychology of environmental attitudes; a cross-cultural study of their content and structure. PhDThesis 2007.

[3] Mądrzycki T. Psychologiczne prawidłowości kształtowania się postaw [Psychological regularities of attitude formation]. Warszawa: WSiP; 1997. Polish

[4] Sinclair B. Outdoor Education - Mostly Getting Out or Getting Most Out? Phys Educ Teach. 1990;7(3):1-2.

[5] Hughes JR. A review of education outside the classroom in New Zealand. Asia J Phys Educ. 1987;2:51-61. https:// doi.org/10.1002/ace.36719873408

[6] Gray R, Gray T. Integrating Outdoor Education into the School Curriculum - A Case Study. Journal of the International Council for Health Physical Education and Recreation1993; 4:6-11.

[7] Hore M. Outdoor and Adventurous Activities in the PE National Curriculum. Br J Phys Educ. 1993;24(2):8-9.

[8] Martin B. Outdoor leadership: theory and practice, Human Kinetics: Champaign, Ill. 2006.

[9] Lobmeyer H, Lutter H. The incorporation of environment al education in school sports. Int J Phys Educ. 1990;27(3):20-26.

[10] Testevuide S. Contenus d'enseignement. Education Physique et Sport. 1993;243:68-70.

[11] Constant M. Activities physiques de pleine nature et EPS. Education Physique et Sport 1994; 44(245): 63-64. https:// doi.org/10.1080/07303084.1990.10606507

[12] Toohey JV. What health educators need to know about the ecology of physical activity in a polluted environment. J American College Health Association 1974; 23(2): 143-145. https://doi.org/10.1080/07303084.1990.10606508

[13] Atkinson G. Outdoor Recreation's Contribution to Environmental Attitudes. J Phys Educ Recreat Dance. 1990; 61(4):46-48.

[14] Bammel L, Bammel G. Outdoor / Environmental Education - An Overview for the Wise Use of Leisure. J Phys Educ Recreat Dance. 1990;61(4):49-54.

[15] Anthony A. The outdoors, Journal of the Canadian Association for Health. Phys Educ Recreat. 1990; 56(4):16-19.

[16] Frołowicz T. Skuteczność procesu wychowania fizycznego w szkole podstawowej [Effectiveness of the physical education process in primary school]. Gdańsk: AWF; 1994. Polish.

[17] Pańczyk W. Biological-medical and didactic results of Physical Education class held outdoors and indoors. Zamość: ODN; 1999.

[18] Pilch T. Zasady badań pedagogicznych [Principles of pedagogical research].Warszawa: Żak; 1995.Polish

[19] Leeming F, Dwyer W, Bracken B. Children's Environmental Attitude and Knowledge Scale: Construction and Validation. J Environ Educ. 1995;26(3):22-31. https://doi.org/10.1080/00958964.1995.9941442

[20] Ogunjinmi AA, Oluwatuyi BG, Oniya BJ. Determining ecological knowledge and attitudes of students: the role of personal factors and school exposure. IntJ Conservation Sci. 2015;6(3):427-436.

[21] Van den Berg A, Koole SL, Van der Wulp NY. Environmental preference and restoration: (How) are they related? J Environ Psychol. 2003;23:135-146. https://doi.org/10.1016/S0272-4944(02)00111-1

[22] Abd El-Salam MM, El-Naggar HM, Hussein RA. Environmental education and its effect on the knowledge and attitudes of preparatory school students. J Egyptian Public Health Association. 2009;84(3-4):345-369. 